\title{
A new perspective of benevolent loan, Qard Al-Hassan, using upfront payment 'Mesbah Point'
}

\author{
Amir Behnam Izadyar ${ }^{*}$, Feroza Ragnath $b$ \\ a Darulmaali Financial Consulting Group, LLC, Maryland, USA. \\ b Darulmaali Financial Consulting Group, LLC, Maryland, USA. E-mail: feroz@darulmaali.com \\ *Corresponding author e-mail: Amir@darulmaali.com
}

\section{H I G H L I G H T S:}

1. This paper introduces a new method in benevolent lending using optimum amount of upfront payment.

2. Profitability of the new method in comparison with a conventional method has been addressed.

3. The finding promotes the presence of institutional investors and discusses some common misconceptions in Qrad al-hassan.

4. Recommendations for using Mebash Point as a new Islamic finance method and creating a secondary market in benevolent loan have been made.

\section{Article History}

Received: 24-04-2014

Accepted: 26-06-2014

Available online: 29-06-2014

Keywords:

Benevolent loan;

Islamic Finance;

Mesbah finance;

Microfinance;

Qard al-hasan.

\begin{abstract}
Bound by religious or moral beliefs of the participants, benevolent loan, Qard al-hasan, is an interest free loan in which only the return of the capital is required during the term of the loan. Lack of institutional investor participation, as well as high administrative fees, are some of the major obstacles that have kept Qard al-hasan from gaining popularity in financial lending. This study has demonstrated a new method in Qard al-hasan lending using Mesbah Point to promote Qard al-hasan as a viable lending transaction. Based on this method the borrower initially makes an optimum amount of upfront payment to receive a zero percent interest rate, no fee loan. The distribution of remaining principal has been studied under two scenarios; Standard MP and Accelerated MP. Based on Mesbah Finance platform the Qard al-hasan lenders and the financial institutions can gain sufficient returns which may help them to cope with their accruing costs as well as earn some profit by providing Qard al-hasan. Although the rate of return in this method unsurprisingly remains below the conventional method, accelerating the monthly payments to the level of conventional monthly payments significantly improves these shortfalls and offsets the gap of return. Accelerated MP shortens the payback period especially in longer loan terms as well as increases the earnings to the level that the participation of institutional investors are possible. The institutionalization of Qard al-hasan is the ultimate aspiration in the Islamic banking system and this study meets the most challenging Islamic lending practice which is Qard al-hasan.
\end{abstract}

DOI: http://dx.doi.org/10.18533/jefs.v2i02.72

JEL Classification:

G15; G21; G23.

(C) 2014 The Authors. This is an open access article under the terms of the Creative Commons Attribution License 4.0, which allows use, distribution and reproduction in any medium, provided the original work is properly cited.

\subsection{Introduction}

Bound by religious or moral beliefs of the participants, Qard al-Hasan (benevolent loan), is an interest free loan in which only the return of the capital is required during the term of the loan. In several aspects, the application of Qard al-hasan $(\mathrm{QH})$ has been scattered among underprivileged communities. It has been used in satisfying the social needs of communities in marriages, education and situations beyond the control of the applicant like prolonged delay in salaries or wages (Farook, 2007). Among community investment clubs this tool has been used as 
a monthly draw to determine who will get the pot of money for that month. Some companies have used QH to lend to its employees for a short period of time where the payment is directly withdrawn from the employees salaries. Savings accounts and certificates of deposits have been structured where the client provides an interest-free loan to the bank through deposits and the bank may utilize the funds for its own means (Bakar, 2008a). Charge cards and credit cards are issued by the banks to their clients based on charging fees and structured on the principles of QH (Bakar, 2008b). Berthoud \& Hinton (1989) noted that credit unions possessed with co-operative financial structures, offer loans that are funded by the pool of savings from members themselves. Credit unions main objective is to act as the promoter of thrift. They believe the credit unions are not formed to make profits, rather to maximize the benefit to their members through financial gains as well as other social factors such as financial education. Mirakhor and Iqbal (2007) have reported that the QH funds in Iran consist of funds from the bank itself but also include contributions from other individuals, financial corporations, business organizations and even the government. However, the banks (mostly state-owned) collaborate with local mosques, religious organizations, and at times with professional associations to extend small consumer QH loans. The QH fund is made up of contributions by the well-off and capable individuals of society who have guarantee on their capital by the banks and they are free to withdraw their funds any time they desire. There is no interest charges involved, but some funds do charge administrative costs to the recipients.

The current view of QH has been focused on introducing $\mathrm{QH}$ as a financial, humanitarian, and welfare tool which would alleviate inequalities and mobilize the wealth in societies by helping impoverished and disadvantaged people (Farooq, 2010; Obaidullah \&Tariqullah, 2008; Khan, 2008; Mojtahed \& Hassanzadeh, 2009; Najeeb \& Lahsasna, 2012). These contemporary studies have established the role of QH on amelioration of the human condition through religious avenues as well as the historical data collected from various countries in the past couple of decades. While the concept is widely used in providing microfinance by NGOs, charities, religious organizations, etc. (Khan, 2008), the results have not been satisfactory in alleviating poverty, improving conditions and gaining popularity among Muslim communities due to several reasons. According to Widiyanto, Mutamimah, \& Hendar (2011) providing QH financing to the poor cannot alleviate poverty on its own and requires a more integrated approach which also involves broader aspects such as education, information and morality. Extending financing through QH has been inadequate and inefficient in alleviating poverty mainly due to the lack of ability to profit from it, high administrative and transaction costs, high risk and lack of demand from recipients (Ariffin \& Adnan, 2011). To absorb losses and inject more capital to $\mathrm{QH}$, several authors have recommended using charities and donations in conjunction with QH so that the issue of lack of funding can be remedied (Ahmed, 2007; Febianto \& Ashany, 2012). According to Farooq (2007), one of the advantages of QH funding is that the source of financing can be originated from the local community so that the QH financing model does not rely on the government or commercial sources. Despite exciting developments in individual practices of charities and donations, there is much work remaining in terms of putting these pieces back into a holistic system to address social economic problems (Ahmed, 2007).

The lack of sufficient access to capital and despondency among institutional investor participants have prevented $\mathrm{QH}$ to grow in the financial cycles mainly based on the assumption that benevolent loan is only a nonprofit and "free-loan". Unfortunately, this presumption has not been sufficiently challenged or the possibilities not fully explored by scholars to provide an alternative viable QH method. Lack of institutional investor participation as well as the high administrative fees are some of the major obstacles that have kept $\mathrm{QH}$ gaining popularity in financial lending. In this article, the authors have addressed these issues and demonstrated a method in which QH is given a new perspective among key participants and consequently bring more liquidity to QH financial market.

\subsection{Methods and analysis}

In the authors' view, $\mathrm{QH}$ is an interest-free loan in which the same amount of principal is returned to the lender at no extra charge to the borrower. In brief, MP is the vertex point of the parabolic curve shape resulted from calculating the discounted values of the total interest paid by the borrower in each interest rate between 1\%-30\% at each 5,10,15,20 and 30 years term in a conventional loan. For further reading on the concept of MP, refer to the previous article (Izadyar and Ragnath 2014). Previously, the MP was discounted based on compounding monthly $(n=12)$ in the time value of money formula (TVM).

Table 1 shows the amount of MP and associated interest rates at each term based on biannual compounding factor $(n=2)$. The assumption is that the amount of cash flow will be invested in sukuk (Islamic bonds) where the compounding is generally in biannual frequencies. Our intent is to introduce an interest free and no fee QH lending platform in which the borrower initially makes MP upfront payment and receives a zero percent interest rate, no fee loan and pays the remaining principal during the term of the loan. The MP upfront payment as well as the remaining principal monthly cash inflows will be invested in profit bearing sukuk.

Table 01: The optimum amount of upfront payment "Mesbah Point" (MP) and associated interest rate based on $30,20,15,10$ and 5 year terms 


\begin{tabular}{lll}
\hline Period & Interest Rate & MP \\
\hline 30 years & $3.875 \%$ & $\$ 21,908.00$ \\
20 years & $6.000 \%$ & $\$ 22,054.76$ \\
15 years & $8.000 \%$ & $\$ 22,204.30$ \\
10 years & $12.250 \%$ & $\$ 22,506.76$ \\
5 years & $26.250 \%$ & $\$ 23,462.92$ \\
\hline
\end{tabular}

Table 2 (see appendix) demonstrates the future value of invested MP and future values of monthly cash inflows on a $\$ 100,000$ QH loan at the rate of return of $3.875 \%$ on a 30 years term. Based on this example, in order for the borrower to receive a $\$ 100,000 \mathrm{QH}$ loan, the borrower will need to make an initial payment of $\$ 21,908$ (MP) and agrees to make the monthly payments of $\$ 216.92$ for the next 30 years $(\$ 100,000$ - $\$ 21,908 / 360)$. The lender at its own discretion will invest the amount of received cash inflows in the financial markets. Assuming the cash flows are invested in sukuk at the annual rate of return of $3.875 \%$ and the gains are compounded semi-annually, the total amount can reach $\$ 214,555.77$. The borrower is making an initial contribution of $\$ 21,908$ and total monthly payments of $\$ 78,092$ ( $\$ 216.92 \times 360$ ) during the term of the loan which equals $\$ 100,000$, while the lender has been able to accelerate its gains by investing the upfront payment and the future cash inflows in a new investment vehicle.

The remaining principal after making the upfront payment (MP) can be distributed in a regular monthly schedule during the full term of the loan (Standard MP) or the monthly payment can be accelerated to the conventional monthly level based on the market condition in order to produce more gains to the lender (Accelerated MP). Table 3 shows the amount of future value (FV) of $\$ 100,000$ loan under conventional, Standard MP and Accelerated MP at interest rates $1 \%$ to $30 \%$ during the terms $5,10,15,20$ and 30 years. The rate of return has been calculated using CAGR (compounding annual growth rate). CAGR $=$ [(ending value/beginning value) $1 / \mathrm{n}]-1$ where $\mathrm{n}$ is the number of years. The FV of a $\$ 100,000$ conventional loan is the FV of monthly received cash inflows which is invested in the market interest rate. Assuming the compounding will occur every 6 months, the formula used to determine FV is $\mathrm{FV}=\mathrm{C}[(1+\mathrm{i}) \mathrm{n}-1 / \mathrm{i}]$ where $\mathrm{C}$ is the cash flow or the monthly payment per period (6 months), $\mathrm{i}$ is equal the semiannual interest rate (annual interest rate/2) and $n$ is twice number of the years (term $x$ 2). The FV of Standard MP scenario is based on the FV of the cash inflows or the monthly payments per period (6months) as just discussed plus the FV of the MP in each term using the data of table 1 . The monthly payment is based on $(\$ 100,000-\mathrm{MP}) /$ term and $\mathrm{FV} \mathrm{MP}=\mathrm{MP}(1+\mathrm{i}) \mathrm{n}$, where $\mathrm{i}$ is equal the semi-annual interest rate and $\mathrm{n}$ is the term times 2 .

The FV of Accelerated MP scenario is conducted in two stages; the first stage is to calculate the FV1 in which the FV of MP and the conventional monthly payment during M period is estimated (table 3 ). The value of M is calculated using $\mathrm{M}=(100,000-\mathrm{MP}) /$ conventional monthly payment. $\mathrm{M}$ is the total of months in which the remaining principal balance will be paid and it is the period that the $\$ 100,000 \mathrm{QH}$ loan will be paid off. In order to calculate FV1, the M needs to be changed to semiannual period, meaning it be divided to 6 . The remaining period is term-M in which the second stage of FV2 will be calculated. In this stage, the amount of FV1 will be used as the PV (present value) in estimating FV2; FV2 = FV1 $(1+\mathrm{i}) \mathrm{n}$, where $\mathrm{i}$ is based on the semi-annual rate and $\mathrm{n}$ is (monthly term-M)/6.

By increasing the monthly payments to conventional level, not only will CAGR achieve a higher percentage (Figure 1 ), but also the payback period is reduced (column $\mathrm{M}$ in table 3) depending upon the interest rate in the market. The borrower's monthly payment will be higher as the interest rates in the market move up. Figure 1 shows the CAGR of the three lending scenarios; conventional, Standard MP and Accelerated MP at interest rates ranging from $1 \%$ to $30 \%$ in a 30 years loan. Although the rate of return in Accelerated MP is less than the rate of return in conventional method, it provides better return in comparison with Standard MP. The percentage of CAGR shortfalls in Standard and Accelerated MP have been compared with conventional method at interest rates $1 \%$ to $30 \%$ during $5,10,15,20$ and 30 years terms in figure 2 . The performance of the investment has a negative relationship with the term and the interest rate in the market; the shorter the term of the loan or the higher the interest rates in the market, the worse the return. Accelerated MP reduces the rate of shortfalls in each term.

Payback period is the time in which the initial principal is expected to be recovered from the cash inflows generated by the investment. It is a quick and simple tool in measuring the period that the initial capital is at risk. Generally, a lower payback period suggests lower risk. Figure 3 illustrates the payback period of $\$ 100,000$ in Accelerated MP at interest rates $1 \%-30 \%$ during 5,10,15,20 and 30 years terms. Depending upon the market conditions, the higher the interest rate in the market, the shorter the payback period is as higher amounts of monthly payments are made (figure 3 in appendix).

\subsection{Discussion}

The latest financial turmoil starting in 2007 has caused irreversible regulatory consequences in the financial market in which a more conservative approach has been mapped into the structure of capitalism. The attempt is to deviate from the expectation of conceptual conventional returns and lean toward more realistic and stable returns whereby 
exploitation can be eliminated in society and thus prevent the accumulation of wealth in the hands of few. Meanwhile, the emergence of alternative financing such as Islamic finance and microfinance has been accelerated as new tools in combating against the societal dysfunctions such as inequalities and poverty.

The scholarly view of $\mathrm{QH}$ has been restricted to application of this financial tool in alleviating poverty and financial justice, although the comprehensive aspects of $\mathrm{QH}$ has not been fully explored and is shrouded in misunderstandings. Obscurity in profitability of $\mathrm{QH}$ has made many believe that $\mathrm{QH}$ is a non-viable financial instrument in the contemporary financial lending system. The current misconception of QH as a charity loan has prevented institutional investors to enter such a market. While QH should not be confused with charity and donation, it is a loan that should be offered to everyone; it is not just for the poor and needy but for the rich and prosperous as well. QH is an ultimate, a final financial lending destination and a benevolent loan. It is a free loan to all society members and can be funded by sources from charities and donations but is not loaned as charity or donation. In this respect, QH should not be applied to mendicants where the borrower is unable to return the original principal. The charities and donations funds should help mendicants and other destitute members in the communities such as unemployed and financially distressed families etc. In developed countries, the governments as well as non-profit organizations take responsibility in providing the basic life necessities such as shelter, food stamps where there is still much more help and funds needed. Charities, donations and volunteering for social services play a vital role in supporting such causes. However, QH covers a much broader financial field other than as a tool for charity only.

Meanwhile, the current role of banks and other QH sponsoring institutions have been a double standard; QH has been successfully promoted in consumer checking and savings accounts by the banks where there are no returns committed to depositors and the funds are being used in profit bearing practices. On the other hand, high costs in administration fees are improperly imposed on borrowers and cause higher amount of return of capital to the lender. Obviously, the whole concept of $\mathrm{QH}$ is based on receiving the same amount of principal from the borrower. Imposed administration or compensation fees by banks do not have religious and moral merits and is subject to exploitation and abuse. However, third party charges such as attorney fees are not part of administration fees since these charges are not paid to the banks and banks will accordingly need to distinguish their business from third party practices.

In our view, collecting additional fees to the principal is prohibited in direct-to-consumer related QH transactions. We have presented MP as an interest rate-proof value in which the borrower, regardless of interest rates in the market, can contribute a pre-determined amount of upfront payment to receive interest free, no fee QH loans (table 1). Collecting optimum amount of upfront payment will release the lender to cover all the administrative costs and fees by reinvesting the MP and the future cash flows in a profit bearing account. Reinvesting MP and the remaining monthly principal payment is performed under a separate transaction and the earned future profits are not at the expense of the borrower for the reason that the amount of principal collected is the same. The details of such transaction have been demonstrated as an example in table 2 where the borrower returns the same $\$ 100,000 \mathrm{QH}$ principal during the 30 years period and the cash flows are invested in sukuk.

Based on MP platform the QH lenders and the financial institutions can gain sufficient returns which may help them to cope with their accruing costs as well as earn some profit by providing $\mathrm{QH}$. Although the rate of return in MP financing still remains below the conventional method, accelerating QH remaining monthly payments to the level of conventional monthly payments significantly improve this offset in the gap of return and significantly reduces the payback period (figure 1 and 3). Figure 2 emphasizes the shortfalls in Standard and Accelerated MP in comparison with a conventional method.

Accelerated MP shortens the payback period especially in longer QH loan terms which suggests lower capital risk to the investor (figure 3), at the same time increasing the earnings to the level that the participation of institutional investors are possible. Presence of institutional investors as well as other major participants is a crucial step in making $\mathrm{QH}$ a viable Islamic product. On the one hand they are able to inject the required capital to the local communities, credit unions and small banks and on the other hand they can provide more liquidity through issuing $\mathrm{QH}$ sukuk in the secondary market. A secondary market for the QH funds demand more actions from governments and their related central banks where they need to actively promote establishing QH funds by monetary policies such as guaranteeing QH funds, tax breaks and other financial subsidies. The monetary policies should perform as a compensating factor in conjunction with the $\mathrm{QH}$ funds as there is a shortfall in the rate of return in QH loans in comparison with conventional lending. This way, the institutional investors are enticed to participate and take more responsibilities in this financial reform.

\subsection{Conclusion}


The institutionalization of $\mathrm{QH}$ is the ultimate aspiration in the Islamic banking system and requires a more holistic approach. Establishing a viable QH lending method, devoid of misconceptions, is the first step toward this approach. Then, participation of the regulators as well as institutional investors in creating a secondary market is crucial in providing liquidity and sufficient capital to the QH markets. Here we introduced a new platform to the most challenging Islamic lending practice which is $\mathrm{QH}$ that will allow financial institutions to enter the $\mathrm{QH}$ market with the intention of entrepreneurship. Although our concept is in its infancy and will require support through Sharia scholars in conjunction with proven practical results, this concept is rooted in consumer demand for a true interestfree, no fee product which potentially provides prosperity for the global society.

\section{References}

Ahmed, H., 2007. Waqf-based microfinance: realizing the social role Of Islamic finance. Jeddah: Islamic Development Bank

Ariffin, N.M., \& Adnan, M.K., 2011. Malaysian Islamic banker's perceptions of al-qard al-hasan. Review of Islamic Economics, 15(2): 97-111.

Bakar, M., 2008a. Contracts in Islamic commercial law and their application in modern Islamic financial system. In M. Bakar \& E.R. Engku Ali (Eds.), Essential Readings in Islamic Finance. CERT Publications, Kuala Lumpur, pp. 47-84.

Bakar, M., 2008b. Shari'ah approaches to product development and product enhancement in Islamic banking and finance. In M. Bakar \& E.R. Engku Ali, (Eds.), Essential Readings in Islamic Finance. CERT Publications, Kuala Lumpur, pp. 113-130.

Berthoud, R., \& Hinton, T., 1989. Credit Unions in the United Kingdom. UK: Policy Studies Institute, Printer Publishers Limited.

Farook, S., 2007. On corporate social responsibility of Islamic financial institutions. Islamic Economic Studies, 15(1): 31-46. http://dx.doi.org/10.1163/026805507X247563

Farooq, M.O., 2007. Stipulation of excess in understanding and misunderstanding riba: the al-jassas link. Arab Law Quarterly, 21(4): 285-316. http://dx.doi.org/10.1163/157302511X553985

Farooq, M.0., 2010. Qarḍ ḥasan, wadī‘ah/amānah and bank deposits: applications and misapplications of some concepts in Islamic banking. Arab Law Quarterly, 25(2):115-146.

Febianto, I., \& Ashany, A.M., 2012. The impact of qardul hasan financing using zakah funds on economic empowerment. Asian Business Review, 1(1): 15-20.

Izadyar, A.B. , \& Ragnath, F., 2014. Establishing an interest-free lending platform applying optimum premium, "Mesbah Point", in amortization and time value of money. International Journal of Business and Social Research, 4(1): 1-18.

Khan, A.A., 2008. Islamic Microfinance Theory, Policy and Practice. Birmingham: Islamic Relief Worldwide.

Mirakhor, A., \& Iqbal, Z., 2007. Qard hasan microfinance. New Horizon, 164(2): 18-20.

Mojtahed, A., \& Hassanzadeh, A., 2009. The evaluation of Qard-al-hasan as a microfinance approch in poverty alleviation programs. Money and Economy, 5(2): 1-32.

Najeeb, S.F., \& Lahsasna, A., 2012. Qard hasan: its rules and applications in Islamic finance. Sahulat, 1(2): 11-22.

Obaidullah, O., \& Tariqullah, M.K., 2008. Islamic Microfinance Development Challenges and Initiative. Jeddah: Islamic Development Bank.

Widiyanto, W., Mutamimah, S., \& Hendar, H., 2011. Effectiveness of Qard al-hasan financing as a poverty alleviation model. Economic Journal of Emerging Markets, 3(1): 27-42. 


\section{Appendix: A}

Table 2: Future value (FV) of invested Mesbah Point (MP) and FV of monthly cash inflows on a $\$ 100,000$ loan at the rate of return of $3.875 \%$ on a 30 years term.

\begin{tabular}{|c|c|c|}
\hline Compound & Principal & FV \\
\hline 1 & $\$ 23,209.52$ & $\$ 23,633.99$ \\
\hline 2 & $\$ 24,511.04$ & $\$ 25,393.42$ \\
\hline 3 & $\$ 25,812.56$ & $\$ 27,186.93$ \\
\hline 4 & $\$ 27,114.08$ & $\$ 29,015.20$ \\
\hline 5 & $\$ 28,415.60$ & $\$ 30,878.89$ \\
\hline 6 & $\$ 29,717.12$ & $\$ 32,778.69$ \\
\hline 7 & $\$ 31,018.64$ & $\$ 34,715.30$ \\
\hline 8 & $\$ 32,320.16$ & $\$ 36,689.42$ \\
\hline 9 & $\$ 33,621.68$ & $\$ 38,701.80$ \\
\hline 10 & $\$ 34,923.20$ & $\$ 40,753.17$ \\
\hline 11 & $\$ 36,224.72$ & $\$ 42,844.28$ \\
\hline 12 & $\$ 37,526.24$ & $\$ 44,975.91$ \\
\hline 13 & $\$ 38,827.76$ & $\$ 47,148.84$ \\
\hline 14 & $\$ 40,129.28$ & $\$ 49,363.87$ \\
\hline 15 & $\$ 41,430.80$ & $\$ 51,621.81$ \\
\hline 16 & $\$ 42,732.32$ & $\$ 53,923.50$ \\
\hline 17 & $\$ 44,033.84$ & $\$ 56,269.79$ \\
\hline 18 & $\$ 45,335.36$ & $\$ 58,661.54$ \\
\hline 19 & $\$ 46,636.88$ & $\$ 61,099.63$ \\
\hline 20 & $\$ 47,938.40$ & $\$ 63,584.95$ \\
\hline 21 & $\$ 49,239.92$ & $\$ 66,118.43$ \\
\hline 22 & $\$ 50,541.44$ & $\$ 68,701.00$ \\
\hline 23 & $\$ 51,842.96$ & $\$ 71,333.60$ \\
\hline 24 & $\$ 53,144.48$ & $\$ 74,017.21$ \\
\hline 25 & $\$ 54,446.00$ & $\$ 76,752.81$ \\
\hline 26 & $\$ 55,747.52$ & $\$ 79,541.41$ \\
\hline 27 & $\$ 57,049.04$ & $\$ 82,384.05$ \\
\hline 28 & $\$ 58,350.56$ & $\$ 85,281.76$ \\
\hline 29 & $\$ 59,652.08$ & $\$ 88,235.61$ \\
\hline 30 & $\$ 60,953.60$ & $\$ 91,246.70$ \\
\hline
\end{tabular}

\begin{tabular}{|c|c|c|}
\hline Compound & Principal & FV \\
\hline 31 & $\$ 62,255.12$ & $\$ 94,316.12$ \\
\hline 32 & $\$ 63,556.64$ & $\$ 97,445.02$ \\
\hline 33 & $\$ 64,858.16$ & $\$ 100,634.54$ \\
\hline 34 & $\$ 66,159.68$ & $\$ 103,885.85$ \\
\hline 35 & $\$ 67,461.20$ & $\$ 107,200.16$ \\
\hline 36 & $\$ 68,762.72$ & $\$ 110,578.68$ \\
\hline 37 & $\$ 70,064.24$ & $\$ 114,022.66$ \\
\hline 38 & $\$ 71,365.76$ & $\$ 117,533.37$ \\
\hline 39 & $\$ 72,667.28$ & $\$ 121,112.10$ \\
\hline 40 & $\$ 73,968.80$ & $\$ 124,760.17$ \\
\hline 41 & $\$ 75,270.32$ & $\$ 128,478.92$ \\
\hline 42 & $\$ 76,571.84$ & $\$ 132,269.72$ \\
\hline 43 & $\$ 77,873.36$ & $\$ 136,133.96$ \\
\hline 44 & $\$ 79,174.88$ & $\$ 140,073.08$ \\
\hline 45 & $\$ 80,476.40$ & $\$ 144,088.51$ \\
\hline 46 & $\$ 81,777.92$ & $\$ 148,181.75$ \\
\hline 47 & $\$ 83,079.44$ & $\$ 152,354.29$ \\
\hline 48 & $\$ 84,380.96$ & $\$ 156,607.67$ \\
\hline 49 & $\$ 85,682.48$ & $\$ 160,943.47$ \\
\hline 50 & $\$ 86,984.00$ & $\$ 165,363.27$ \\
\hline 51 & $\$ 88,285.52$ & $\$ 169,868.70$ \\
\hline 52 & $\$ 89,587.04$ & $\$ 174,461.43$ \\
\hline 53 & $\$ 90,888.56$ & $\$ 179,143.14$ \\
\hline 54 & $\$ 92,190.08$ & $\$ 183,915.56$ \\
\hline 55 & $\$ 93,491.60$ & $\$ 188,780.44$ \\
\hline 56 & $\$ 94,793.12$ & $\$ 193,739.58$ \\
\hline 57 & $\$ 96,094.64$ & $\$ 198,794.80$ \\
\hline 58 & $\$ 97,396.16$ & $\$ 203,947.97$ \\
\hline 59 & $\$ 98,697.68$ & $\$ 209,200.99$ \\
\hline 60 & $\$ 100,000.00$ & $\$ 214,555.77$ \\
\hline
\end{tabular}




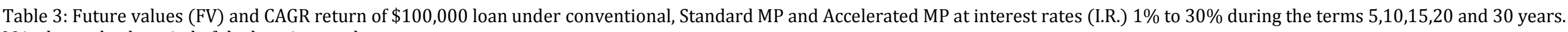
$M$ is the payback period of the loan in months.

\begin{tabular}{|c|c|c|c|c|c|c|c|c|c|c|c|}
\hline \multirow{2}{*}{\begin{tabular}{l|} 
\\
I.R. \\
\end{tabular}} & \multicolumn{2}{|l|}{30 years } & \multirow[b]{2}{*}{ FV } & \multicolumn{3}{|c|}{ Standard MP } & \multicolumn{5}{|c|}{ Accelerated MP } \\
\hline & Monthly & Total payment & & Monthly & FV MP & CAGR & M & FV1 & $360-M$ & FV2 & CAGR \\
\hline $1 \%$ & 21.64 & $\$ 115,790.23$ & $\$ 134,644.79$ & 216.92 & $\$ 120,358.63$ & $0.62 \%$ & 242.79 & $\$ 113,122.16$ & 117.21 & $\$ 124,698.27$ & $0.74 \%$ \\
\hline $2 \%$ & $\$ 369.62$ & $\$ 133,063.01$ & $\$ 181,120.20$ & 216.92 & $\$ 146,095.99$ & $1.27 \%$ & 211.28 & $\$ 124,157.30$ & 148.72 & $\$ 158,886.52$ & $1.56 \%$ \\
\hline $3 \%$ & $\$ 421.60$ & $\$ 151,777.45$ & $\$ 243,386.91$ & $\$ 216.92$ & $\$ 178,752.64$ & $1.95 \%$ & 185.23 & $\$ 133,090.26$ & 174.77 & $05,350.47$ & $2.43 \%$ \\
\hline $4 \%$ & 77.42 & $71,869.51$ & $26,699.70$ & $\$ 216.92$ & $\$ 220,322.70$ & $2.67 \%$ & 163.57 & $\$ 140,104.62$ & 196.43 & $\$ 267,919.42$ & $3.34 \%$ \\
\hline $5 \%$ & 36.82 & 5.78 & 9.36 & 216.92 & 8.18 & $3.41 \%$ & 145.47 & $\$ 145,475.21$ & 214.53 & 7.72 & $4.28 \%$ \\
\hline $6 \%$ & 99.55 & $15,838.19$ & $\$ 586,552.64$ & 216.92 & $\$ 341,292.72$ & $4.18 \%$ & 130.25 & $\$ 149,496.58$ & 229.75 & 7.64 & 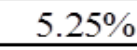 \\
\hline $7 \%$ & $\$ 665.30$ & $9,508.90$ & $\$ 784,459.04$ & 216.92 & $\$ 428,366.49$ & $4.97 \%$ & 117.38 & $\$ 152,443.24$ & 242.62 & 03.88 & $6.23 \%$ \\
\hline $8 \%$ & 3.76 & $4,155.25$ & $\$ 1,047,774.80$ & 92 & & $5.78 \%$ & & & & & \\
\hline $9 \%$ & $\$ 804.62$ & $9,664.14$ & $\$ 1,397,619.61$ & $\$ 216.92$ & 3.69 & $6.62 \%$ & 97.05 & 7.48 & 262.95 & $\$ 1$, & $8.23 \%$ \\
\hline $10 \%$ & $\$ 877.57$ & $\$ 315,925.77$ & $\$ 1,861,770.11$ & 216.92 & $\$ 869,424.60$ & $7.48 \%$ & 88.99 & $\$ 156,994.81$ & 271.01 & 73.33 & $9.25 \%$ \\
\hline $11 \%$ & $\$ 952.32$ & 836.42 & $\$ 2,476,709.58$ & 216.92 & .80 & $8.35 \%$ & 82 & $7,604.81$ & 278 & 4.19 & $10.28 \%$ \\
\hline $12 \%$ & $1,028.61$ & .53 & .18 & & & $9.24 \%$ & 5.92 & & 34.08 & & \\
\hline $13 \%$ & 6.20 & & .12 & 92 & & & 70.59 & .46 & 9.41 & & \\
\hline $14 \%$ &, 184.87 & .83 & 3.93 & 5.92 & 4.22 & $11.06 \%$ & 65.91 & 1.57 & 294.09 & 6.83 & $13.41 \%$ \\
\hline $15 \%$ & $\$ 1,264.44$ & $5,199.85$ & $\$ 7,652,338.38$ & $\$ 216.92$ & 1.66 & $12.00 \%$ & 61.76 & .29 & 298.24 & $\$ 5,749,7$ & $14.46 \%$ \\
\hline $16 \%$ & $\$ 1,344.76$ & $1,112.52$ & $\$ 10,111,604.09$ & $\$ 216.92$ & $9,438.63$ & $12.94 \%$ & 58.07 & $7,707.28$ & 301.93 & $\$ 7,581,980.93$ & $15.52 \%$ \\
\hline $17 \%$ & $\$ 1,425.68$ &, 243.12 & $\$ 13,343,634.99$ & $\$ 216.92$ & & $13.90 \%$ & 54.78 & $\$ 157,434.57$ & 305.22 & $\$ 9,987,0$ & \\
\hline $18 \%$ & & & & & & $6 \%$ & & & 18 & & \\
\hline $19 \%$ & $\$ 1,588.89$ & $\$ 572,001.30$ & $\$ 23,146,776.98$ & $\$ 216.92$ & $\$ 8,235,256.11$ & $15.84 \%$ & 49.15 & $\$ 156,771.34$ & 310.85 & $\$ 17,268,517.23$ & $18.73 \%$ \\
\hline $20 \%$ & $\$ 1,671.02$ & $\$ 601,566.73$ & $\$ 30,427,409.44$ & $\$ 216.92$ & $\$ 10,620,498.46$ & $16.83 \%$ & 46.73 & $\$ 156,401.93$ & 313.27 & $\$ 22,667,379.24$ & $19.82 \%$ \\
\hline $21 \%$ & $\$ 1,753.40$ & $\$ 631,224.03$ & $\$ 39,947,697.37$ & $\$ 216.92$ & $\$ 13,698,815.57$ & $17.82 \%$ & 44.54 & $\$ 156,016.94$ & 315.46 & $\$ 29,718,992.45$ & $20.90 \%$ \\
\hline $22 \%$ & $\$ 1,835.98$ & $\$ 660,954.52$ & $\$ 52,381,371.16$ & $\$ 216.92$ & $\$ 17,669,922.76$ & $18.82 \%$ & 42.53 & $\$ 155,621.27$ & 317.47 & $\$ 38,918,148.97$ & $21.99 \%$ \\
\hline $23 \%$ & $\$ 1,918.73$ & $\$ 690,743.09$ & $\$ 68,600,329.45$ & & $\$ 22,790,314.53$ & $19.84 \%$ & 40.7 & $\$ 155,218.56$ & 319.3 & $0,904,468.80$ & $23.09 \%$ \\
\hline $24 \%$ & $\$ 2,001.60$ & $\$ 720,577.59$ & $\$ 89,731,618.98$ & $\$ 216.92$ & $\$ 29,389,143.58$ & $20.86 \%$ & 39.01 & $\$ 154,811.45$ & 320.99 & $\$ 66,5$ & $24.19 \%$ \\
\hline $25 \%$ & $\$ 2,084.58$ & $\$ 750,448.31$ & $\$ 117,230,425.46$ & $\$ 216.92$ & $\$ 37,888,459.57$ & $21.88 \%$ & 37.46 & $\$ 154,401.92$ & 322.54 & $\$ 86,781,415.30$ & $25.30 \%$ \\
\hline $26 \%$ & $\$ 2,167.63$ & $\$ 780,347.51$ & $\$ 152,973,470.56$ & $\$ 216.92$ & $\$ 48,828,981.21$ & $22.92 \%$ & 36.03 & $\$ 153,991.41$ & 323.97 & $\$ 113,109,424.95$ & $26.41 \%$ \\
\hline $27 \%$ & $\$ 2,250.75$ & $\$ 810,269.05$ & $\$ 199,378,388.78$ & $\$ 216.92$ & $\$ 62,902,884.58$ & $23.96 \%$ & 34.7 & $\$ 153,580.97$ & 325.3 & $\$ 147,253,652.54$ & $27.53 \%$ \\
\hline $28 \%$ & $\$ 2,333.91$ & $\$ 840,208.08$ & $\$ 259,556,144.78$ & $\$ 216.92$ & $\$ 80,995,479.80$ & $25.01 \%$ & 33.46 & $\$ 153,171.38$ & 326.54 & $\$ 191,483,804.56$ & $28.65 \%$ \\
\hline $29 \%$ & $\$ 2,417.11$ & $\$ 870,160.76$ & $\$ 337,505,425.67$ & $\$ 216.92$ & $\$ 104,238,137.11$ & $26.07 \%$ & 32.31 & $\$ 152,763.20$ & 327.69 & $\$ 248,714,086.82$ & $29.77 \%$ \\
\hline $30 \%$ & $\$ 2,500.34$ & $\$ 900,124.08$ & $\$ 438,360,302.77$ & $\$ 216.92$ & $\$ 134,075,437.64$ & $27.13 \%$ & 31.23 & $\$ 152,356.84$ & 328.77 & $\$ 322,682,112.52$ & $30.91^{\circ}$ \\
\hline
\end{tabular}




\begin{tabular}{|c|c|c|c|c|c|c|c|c|c|c|c|}
\hline & $\begin{array}{r}20 \text { years } \\
\text { Conv }\end{array}$ & entional & & & andard MP & & & & erated & & \\
\hline I.R. & Monthly & Total payment & $\mathrm{FV}$ & Monthly & FV MP & CAGR & $\mathrm{M}$ & FV1 & $240-\mathrm{M}$ & FV2 & CAGR \\
\hline $1 \%$ & $\$ 459.89$ & $\$ 110,374.63$ & $\$ 121,850.41$ & $\$ 324.77$ & $\$ 112,973.62$ & $0.61 \%$ & 169.49 & $\$ 108,886.05$ & 70.51 & $\$ 115,459.28$ & $0.72 \%$ \\
\hline $2 \%$ & 505.88 & $\$ 121,412.00$ & $\$ 148,384.81$ & $\$ 324.77$ & $\$ 128,098.03$ & $1.25 \%$ & 154.08 & $\$ 116,843.32$ & 85.92 & $\$ 134,737.28$ & $1.50 \%$ \\
\hline $3 \%$ & 554.60 & $\$ 133,103.42$ & $\$ 180,581.06$ & $\$ 324.77$ & $\$ 145,755.84$ & $1.90 \%$ & 140.54 & $\$ 123,830.48$ & 99.46 & $\$ 158,492.58$ & $2.33 \%$ \\
\hline $4 \%$ & 505.98 & $145,435.28$ & $\$ 219,614.48$ & 324.77 & $\$ 166,398.96$ & $2.58 \%$ & 128.63 & $\$ 129,862.90$ & 111.37 & $\$ 187,552.72$ & $3.19 \%$ \\
\hline $5 \%$ & 559.96 & $158,389.38$ & $\$ 266,896.21$ & 324.77 & $\$ 190,561.14$ & $3.28 \%$ & 118.11 & $\$ 134,994.53$ & 121.89 & $\$ 222,934.50$ & $4.09 \%$ \\
\hline $6 \%$ & 716.43 & $\$ 171,943.45$ & $\$ 324,118.83$ & 324.77 & $\$ 218,872.69$ & $3.99 \%$ & 108.8 & $\$ 139,302.50$ & 131.2 & $\$ 265,872.60$ & $5.01 \%$ \\
\hline $7 \%$ & $\$ 775.30$ & $\$ 186,071.74$ & $\$ 393,310.44$ & $\$ 324.77$ & $\$ 252,077.82$ & $4.73 \%$ & 100.54 & $\$ 142,875.09$ & 139.46 & $\$ 317,856.21$ & $5.95 \%$ \\
\hline $8 \%$ & $\$ 836.44$ & $\$ 200,745.62$ & $\$ 476,898.89$ & $\$ 324.77$ & $\$ 291,055.02$ & $5.49 \%$ & 93.19 & $\$ 145,803.17$ & 146.81 & $\$ 380,674.04$ & $6.91 \%$ \\
\hline $9 \%$ & $\$ 899.73$ & $\$ 215,934.23$ & $\$ 577,787.76$ & $\$ 324.77$ & $\$ 336,841.13$ & $6.26 \%$ & 86.63 & $\$ 148,174.59$ & 153.37 & $\$ 456,468.67$ & $7.89 \%$ \\
\hline $10 \%$ & $\$ 965.02$ & $\$ 231,605.19$ & $\$ 699,446.38$ & 324.77 & $\$ 390,659.45$ & $7.05 \%$ & 80.77 & $\$ 150,070.78$ & 159.23 & 01.47 & $8.88 \%$ \\
\hline $11 \%$ & $\$ 1,032.19$ & & & $\$ 324.77$ & $3,952.92$ & $7.86 \%$ & 75.51 & & 164.49 & $\$ 657,729.77$ & $9.88 \%$ \\
\hline $12 \%$ & $\$ 1,101.09$ & $54,260.67$ & $\$ 1,022,437.53$ & 24.77 & $\$ 528,423.00$ & $8.68 \%$ & 70.79 & $\$ 152,721.83$ & 169.21 & $\$ 789,898.30$ & $10.89 \%$ \\
\hline $13 \%$ & $\$ 1,171.58$ & $81,178.17$ & $\$ 1,234,596.52$ & 24.77 & & $9.52 \%$ & 66.53 & $53,597.17$ & 173.47 & $\$ 948,647.29$ & $11.91 \%$ \\
\hline $14 \%$ & $\$ 1,243.52$ & $98,444.99$ & $\$ 1,489,502.50$ & 24.77 & $\$ 719,273.24$ & $10.37 \%$ & 62.68 & $54,238.89$ & 177.32 & $\$ 1,139,140.06$ & $12.94 \%$ \\
\hline $15 \%$ & $\$ 1,316.79$ & $16,029.50$ & $\$ 1,795,494.11$ & 24.77 & $\$ 840,800.46$ & $11.23 \%$ & 59.19 & $54,687.52$ & 180.81 & $\$ 1,367,513.45$ & $13.97 \%$ \\
\hline $16 \%$ & $\$ 1,391.26$ & $3,901.43$ & 0189 & 4.77 & $3,934.67$ & $12.11 \%$ & 03 & $4,977.17$ & 3.97 & $\$ 1,641,055.00$ & $15.02 \%$ \\
\hline $17 \%$ & 466.80 & 32.13 &, 243.84 & 4.77 &, 533.54 & $0 \%$ & 14 & 6.33 & .86 & $\$ 1,968,411.31$ & $16.07 \%$ \\
\hline $18 \%$ & $\$ 1,543.31$ & $0,394.77$ & $8,747.23$ & 24.77 & $, 351,135.43$ & $13.90 \%$ & 50.51 & 8.71 & 189.49 & $\$ 2,359,833.19$ & $17.12 \%$ \\
\hline $19 \%$ & $\$ 1,620.68$ & $\$ 388,964.36$ & $\$ 3,758,562.58$ & $\$ 324.77$ & $\$ 1,585,077.14$ & $14.82 \%$ & 48.09 & $5,153.92$ & 191.91 & $\$ 2,827,463.40$ & $18.19 \%$ \\
\hline $20 \%$ & $\$ 1,698.82$ & $\$ 407,717.91$ & $\$ 4,511,322.75$ & $\$ 324.77$ & $\$ 1,860,631.59$ & $15.74 \%$ & 45.88 & $\$ 155,048.20$ & 194.12 & $\$ 3,385,674.55$ & $19.26 \%$ \\
\hline $21 \%$ & $\$ 1,777.64$ & $\$ 426,634.31$ & $\$ 5,410,273.13$ & $\$ 324.77$ & $\$ 2,185,168.65$ & $16.67 \%$ & 43.85 & $\$ 154,884.90$ & 196.15 & $\$ 4,051,465.29$ & $20.33 \%$ \\
\hline $22 \%$ & $\$ 1,857.06$ & $\$ 445,694.38$ & $\$ 6,482,915.27$ & $\$ 324.77$ & $\$ 2,567,342.84$ & $17.62 \%$ & 41.97 & $\$ 154,675.01$ & 198.03 & $\$ 4,844,924.66$ & $21.41 \%$ \\
\hline $23 \%$ & $\$ 1,937.00$ & $\$ 464,880.80$ & $\$ 7,761,761.48$ & $\$ 324.77$ & $\$ 3,017,312.43$ & $18.57 \%$ & 40.24 & $\$ 154,427.54$ & 199.76 & $\$ 5,789,775.91$ & $22.50 \%$ \\
\hline $24 \%$ & $\$ 2,017.41$ & $\$ 484,177.96$ & $\$ 9,285,218.89$ & $\$ 324.77$ & $\$ 3,546,994.94$ & $19.53 \%$ & 38.64 & $\$ 154,149.89$ & 201.36 & $\$ 6,914,012.84$ & $23.59 \%$ \\
\hline $25 \%$ & $\$ 2,098.22$ & $\$ 503,571.90$ & $\$ 11,098,624.37$ & $\$ 324.77$ & $\$ 4,170,364.91$ & $20.51 \%$ & 37.15 & $\$ 153,848.10$ & 202.85 & $\$ 8,250,644.04$ & $24.69 \%$ \\
\hline $26 \%$ & $\$ 2,179.38$ & $\$ 523,050.21$ & $\$ 13,255,455.41$ & $\$ 324.77$ & $\$ 4,903,800.77$ & $21.49 \%$ & 35.76 & $\$ 153,527.12$ & 204.24 & $\$ 9,838,562.46$ & $25.79 \%$ \\
\hline $27 \%$ & $\$ 2,260.84$ & $\$ 542,601.87$ & $\$ 15,818,745.55$ & $\$ 324.77$ & $\$ 5,766,488.64$ & $22.47 \%$ & 34.48 & $\$ 153,191.00$ & 205.52 & $\$ 11,723,560.99$ & $26.90 \%$ \\
\hline $28 \%$ & $\$ 2,342.57$ & $\$ 562,217.15$ & $\$ 18,862,738.16$ & $\$ 324.77$ & $\$ 6,780,892.28$ & $23.47 \%$ & 33.27 & $\$ 152,843.05$ & 206.73 & $\$ 13,959,517.54$ & $28.01 \%$ \\
\hline $29 \%$ & $\$ 2,424.53$ & $\$ 581,887.50$ & $\$ 22,474,816.99$ & $\$ 324.77$ & $\$ 7,973,299.39$ & $24.47 \%$ & 32.15 & $\$ 152,485.95$ & 207.85 & $\$ 16,609,777.02$ & $29.13 \%$ \\
\hline $30 \%$ & $\$ 2,506.69$ & $\$ 601,605.40$ & $\$ 26,757,758.54$ & $\$ 324.77$ & $\$ 9,374,456.75$ & $25.49 \%$ & 31.09 & $\$ 152,121.91$ & 208.91 & $\$ 19,748,761.91$ & $30.25 \%$ \\
\hline
\end{tabular}




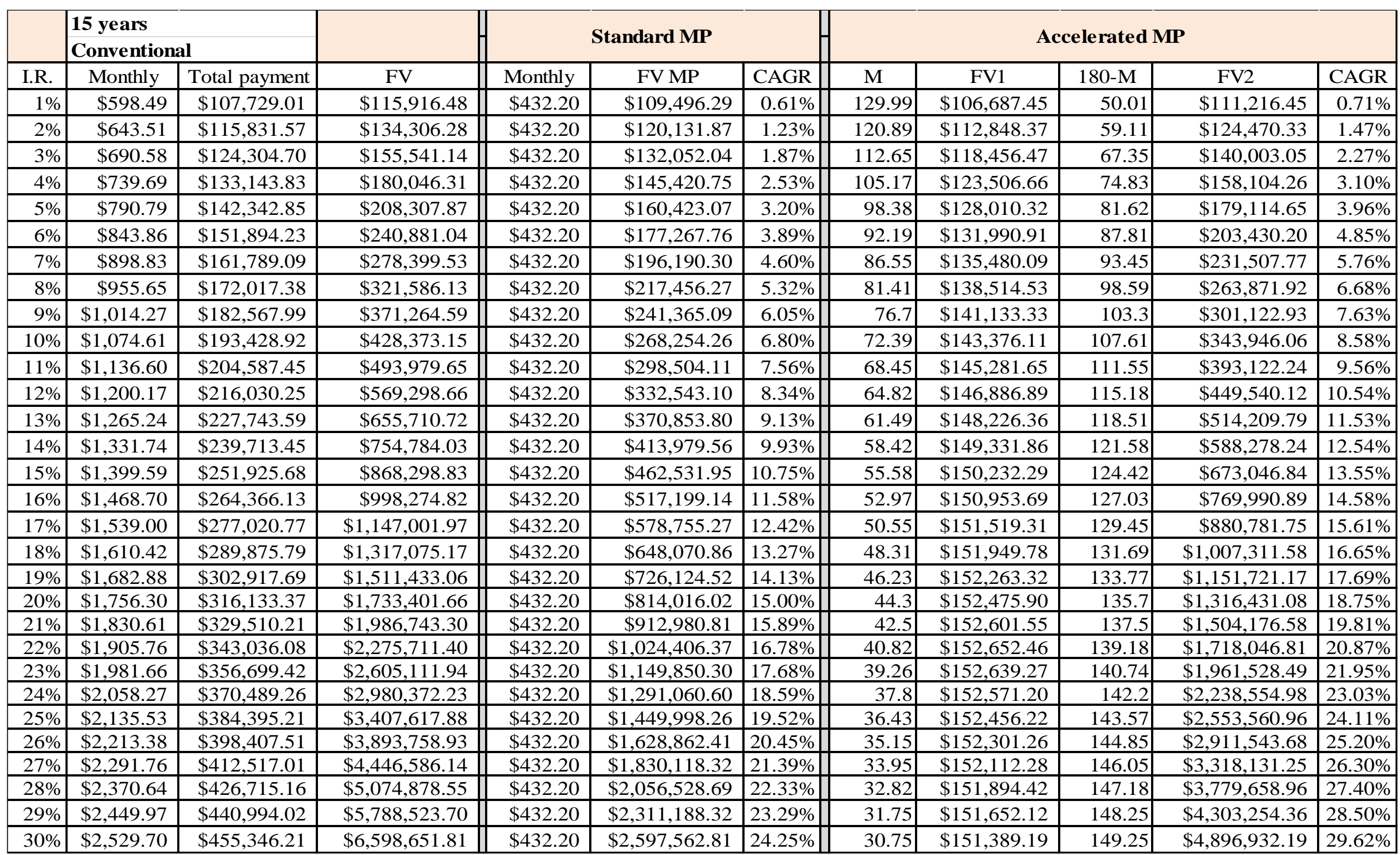




\begin{tabular}{|c|c|c|c|c|c|c|c|c|c|c|c|}
\hline \multirow[b]{2}{*}{ I.R. } & \multicolumn{2}{|c|}{10 Years Conventional } & \multirow[b]{2}{*}{ FV } & \multicolumn{3}{|c|}{ Standard MP } & \multicolumn{5}{|c|}{ Accelerated MP } \\
\hline & Monthly & Total payment & & Monthly & FV MP & CAGR & $\mathrm{M}$ & FV1 & $120-\mathrm{M}$ & FV2 & CAGR \\
\hline $1 \%$ & $\$ 876.04$ & $\$ 105,124.95$ & $\$ 110,271.42$ & $\$ 645.78$ & $\$ 106,154.60$ & $0.60 \%$ & 88.46 & $\$ 104,437.20$ & 31.54 & $\$ 107,211.67$ & $0.70 \%$ \\
\hline $2 \%$ & $\$ 920.13$ & $\$ 110,416.14$ & $\$ 121,562.68$ & $\$ 645.78$ & $\$ 112,778.72$ & $1.21 \%$ & 84.22 & $\$ 108,633.20$ & 35.78 & $\$ 115,274.37$ & $1.43 \%$ \\
\hline $3 \%$ & $\$ 965.61$ & $\$ 115,872.89$ & $\$ 133,970.31$ & $\$ 645.78$ & $\$ 119,909.74$ & $1.83 \%$ & 80.25 & $\$ 112,577.67$ & 39.75 & $\$ 124,247.07$ & $2.19 \%$ \\
\hline $4 \%$ & $\$ 1,012.45$ & $\$ 121,494.17$ & $\$ 147,599.43$ & $\$ 645.78$ & $\$ 127,587.96$ & $2.47 \%$ & 76.54 & $\$ 116,265.20$ & 43.46 & $\$ 134,197.17$ & $2.99 \%$ \\
\hline $5 \%$ & $\$ 1,060.66$ & $\$ 127,278.62$ & $\$ 162,564.44$ & $\$ 645.78$ & $\$ 135,856.86$ & $3.11 \%$ & 73.06 & $\$ 119,694.67$ & 46.94 & $\$ 145,200.53$ & $3.80 \%$ \\
\hline $6 \%$ & $\$ 1,110.21$ & $\$ 133,224.60$ & $\$ 178,989.75$ & $\$ 645.78$ & $\$ 144,763.33$ & $3.77 \%$ & 69.8 & $\$ 122,868.53$ & 50.2 & $\$ 157,341.63$ & $4.64 \%$ \\
\hline $7 \%$ & $\$ 1,161.08$ & $\$ 139,330.18$ & $\$ 197,010.65$ & $\$ 645.78$ & $\$ 154,357.91$ & $4.44 \%$ & 66.74 & $\$ 125,792.19$ & 53.26 & $\$ 170,713.93$ & $5.49 \%$ \\
\hline $8 \%$ & $\$ 1,213.28$ & $\$ 145,593.11$ & $\$ 216,774.16$ & $\$ 645.78$ & $\$ 164,695.07$ & $5.12 \%$ & 63.87 & $\$ 128,473.39$ & 56.13 & $\$ 185,420.18$ & $6.37 \%$ \\
\hline $9 \%$ & $\$ 1,266.76$ & $\$ 152,010.93$ & $\$ 238,439.96$ & $\$ 645.78$ & $\$ 175,833.53$ & $5.81 \%$ & 61.17 & $\$ 130,921.63$ & 58.83 & $\$ 201,573.00$ & $7.26 \%$ \\
\hline $10 \%$ & $\$ 1,321.51$ & $\$ 158,580.88$ & $\$ 262,181.41$ & $\$ 645.78$ & $\$ 187,836.53$ & $6.51 \%$ & 58.64 & $\$ 133,147.73$ & 61.36 & $\$ 219,295.41$ & $8.17 \%$ \\
\hline $11 \%$ & $\$ 1,377.50$ & $\$ 165,300.01$ & $\$ 288,186.67$ & $\$ 645.78$ & $\$ 200,772.21$ & $7.22 \%$ & 56.26 & $\$ 135,163.39$ & 63.74 & $\$ 238,721.50$ & $9.09 \%$ \\
\hline $12 \%$ & $\$ 1,434.71$ & $\$ 172,165.14$ & $\$ 316,659.82$ & $\$ 645.78$ & $\$ 214,713.96$ & $7.94 \%$ & 54.01 & $\$ 136,980.83$ & 65.99 & $\$ 259,997.19$ & $10.03 \%$ \\
\hline $13 \%$ & $\$ 1,493.11$ & $\$ 179,172.89$ & $\$ 347,822.13$ & $\$ 645.78$ & $\$ 229,740.78$ & $8.67 \%$ & 51.9 & $\$ 138,612.50$ & 68.1 & $\$ 283,281.03$ & $10.97 \%$ \\
\hline $14 \%$ & $\$ 1,552.66$ & $\$ 186,319.72$ & $\$ 381,913.44$ & $\$ 645.78$ & $\$ 245,937.74$ & $9.42 \%$ & 49.91 & $\$ 140,070.86$ & 70.09 & $\$ 308,745.08$ & $11.93 \%$ \\
\hline $15 \%$ & $\$ 1,613.35$ & $\$ 193,601.95$ & $\$ 419,193.53$ & $\$ 645.78$ & $\$ 263,396.37$ & $10.17 \%$ & 48.03 & $\$ 141,368.17$ & 71.97 & $\$ 336,575.88$ & $12.90 \%$ \\
\hline $16 \%$ & $\$ 1,675.13$ & $\$ 201,015.75$ & $\$ 459,943.77$ & $\$ 645.78$ & $\$ 282,215.19$ & $10.93 \%$ & 46.26 & $\$ 142,516.36$ & 73.74 & $\$ 366,975.54$ & $13.88 \%$ \\
\hline $17 \%$ & $\$ 1,737.98$ & $\$ 208,557.18$ & $\$ 504,468.68$ & $\$ 645.78$ & $\$ 302,500.17$ & $11.70 \%$ & 44.59 & $\$ 143,526.91$ & 75.41 & $\$ 400,162.81$ & $14.87 \%$ \\
\hline $18 \%$ & $\$ 1,801.85$ & $\$ 216,222.24$ & $\$ 553,097.78$ & $\$ 645.78$ & $\$ 324,365.30$ & $12.49 \%$ & 43.01 & $\$ 144,410.78$ & 76.99 & $\$ 436,374.37$ & $15.87 \%$ \\
\hline $19 \%$ & $\$ 1,866.72$ & $\$ 224,006.83$ & $\$ 606,187.48$ & $\$ 645.78$ & $\$ 347,933.15$ & $13.28 \%$ & 41.51 & $\$ 145,178.37$ & 78.49 & $\$ 475,866.09$ & $16.88 \%$ \\
\hline $20 \%$ & $\$ 1,932.56$ & $\$ 231,906.81$ & $\$ 664,123.11$ & $\$ 645.78$ & $\$ 373,335.49$ & $14.08 \%$ & 40.1 & $\$ 145,839.46$ & 79.9 & $\$ 518,914.47$ & $17.90 \%$ \\
\hline $21 \%$ & $\$ 1,999.32$ & $\$ 239,918.01$ & $\$ 727,321.14$ & $\$ 645.78$ & $\$ 400,713.97$ & $14.89 \%$ & 38.76 & $\$ 146,403.22$ & 81.24 & $\$ 565,818.15$ & $18.92 \%$ \\
\hline $22 \%$ & $\$ 2,066.97$ & $\$ 248,036.25$ & $\$ 796,231.50$ & $\$ 645.78$ & $\$ 430,220.78$ & $15.71 \%$ & 37.49 & $\$ 146,878.21$ & 82.51 & $\$ 616,899.53$ & $19.96 \%$ \\
\hline $23 \%$ & $\$ 2,135.48$ & $\$ 256,257.36$ & $\$ 871,340.10$ & $\$ 645.78$ & $\$ 462,019.47$ & $16.54 \%$ & 36.29 & $\$ 147,272.38$ & 83.71 & $\$ 672,506.52$ & $21.00 \%$ \\
\hline $24 \%$ & $\$ 2,204.81$ & $\$ 264,577.16$ & $\$ 953,171.54$ & $\$ 645.78$ & $\$ 496,285.66$ & $17.37 \%$ & 35.15 & $\$ 147,593.07$ & 84.85 & $\$ 733,014.40$ & $22.04 \%$ \\
\hline $25 \%$ & $\$ 2,274.93$ & $\$ 272,991.54$ & $\$ 1,042,291.95$ & $\$ 645.78$ & $\$ 533,208.00$ & $18.22 \%$ & 34.06 & $\$ 147,847.10$ & 85.94 & $\$ 798,827.80$ & $23.10 \%$ \\
\hline $26 \%$ & $\$ 2,345.80$ & $\$ 281,496.41$ & $\$ 1,139,312.09$ & $\$ 645.78$ & $\$ 572,988.97$ & $19.07 \%$ & 33.03 & $\$ 148,040.69$ & 86.97 & $\$ 870,382.86$ & $24.16 \%$ \\
\hline $27 \%$ & $\$ 2,417.40$ & $\$ 290,087.75$ & $\$ 1,244,890.65$ & $\$ 645.78$ & $\$ 615,845.97$ & $19.94 \%$ & 32.06 & $\$ 148,179.60$ & 87.94 & $\$ 948,149.47$ & $25.22 \%$ \\
\hline $28 \%$ & $\$ 2,489.68$ & $\$ 298,761.62$ & $\$ 1,359,737.74$ & $\$ 645.78$ & $\$ 662,012.26$ & $20.81 \%$ & 31.13 & $\$ 148,269.08$ & 88.87 & $\$ 1,032,633.71$ & $26.30 \%$ \\
\hline $29 \%$ & $\$ 2,562.62$ & $\$ 307,514.13$ & $\$ 1,484,618.65$ & $\$ 645.78$ & $\$ 711,738.11$ & $21.68 \%$ & 30.24 & $\$ 148,313.95$ & 89.76 & $\$ 1,124,380.50$ & $27.38 \%$ \\
\hline $30 \%$ & $\$ 2,636.18$ & $\$ 316,341.52$ & $\$ 1,620,357.91$ & $\$ 645.78$ & $\$ 765,291.99$ & $22.57 \%$ & 29.4 & $\$ 148,318.59$ & 90.6 & $\$ 1,223,976.28$ & $28.46 \%$ \\
\hline
\end{tabular}




\begin{tabular}{|c|c|c|c|c|c|c|c|c|c|c|c|}
\hline \multirow{2}{*}{ I.R. } & \multicolumn{2}{|l|}{5 Years } & \multirow[b]{2}{*}{$\mathrm{FV}$} & \multicolumn{3}{|c|}{ Standard MP } & \multicolumn{5}{|c|}{ Accelerated MP } \\
\hline & Monthly & Total payment & & Monthly & FV MP & CAGR & $\mathrm{M}$ & FV1 & $60-\mathrm{M}$ & FV2 & CAGR \\
\hline $1 \%$ & $\$ 1,709.37$ & $\$ 102,562.48$ & $\$ 104,901.18$ & $\$ 1,275.62$ & $\$ 102,945.14$ & $0.58 \%$ & 44.77 & $\$ 102,137.60$ & 15.23 & $\$ 103,438.47$ & $0.68 \%$ \\
\hline $2 \%$ & $\$ 1,752.78$ & $\$ 105,166.56$ & $\$ 110,027.49$ & $\$ 1,275.62$ & $\$ 105,992.38$ & $1.17 \%$ & 43.67 & $\$ 104,207.22$ & 16.33 & $\$ 107,068.54$ & $1.38 \%$ \\
\hline $3 \%$ & $\$ 1,796.87$ & $\$ 107,812.14$ & $\$ 115,388.34$ & $\$ 1,275.62$ & $\$ 109,145.18$ & $1.77 \%$ & 42.59 & $\$ 106,207.45$ & 17.41 & $\$ 110,895.06$ & $2.09 \%$ \\
\hline $4 \%$ & $\$ 1,841.65$ & $\$ 110,499.13$ & $\$ 120,993.47$ & $\$ 1,275.62$ & $\$ 112,407.14$ & $2.37 \%$ & 41.56 & $\$ 108,137.29$ & 18.44 & $\$ 114,923.33$ & $2.82 \%$ \\
\hline $5 \%$ & $\$ 1,887.12$ & $\$ 113,227.40$ & $\$ 126,852.98$ & $\$ 1,275.62$ & $\$ 115,781.93$ & $2.97 \%$ & 40.56 & $\$ 109,996.08$ & 19.44 & $\$ 119,159.03$ & $3.57 \%$ \\
\hline $6 \%$ & $\$ 1,933.28$ & $\$ 115,996.81$ & $\$ 132,977.34$ & $\$ 1,275.62$ & $\$ 119,273.39$ & $3.59 \%$ & 39.59 & $\$ 111,783.51$ & 20.41 & $\$ 123,608.22$ & $4.33 \%$ \\
\hline $7 \%$ & $\$ 1,980.12$ & $\$ 118,807.19$ & $\$ 139,377.39$ & $\$ 1,275.62$ & $\$ 122,885.42$ & $4.21 \%$ & 38.65 & $\$ 113,499.54$ & 21.35 & $\$ 128,277.36$ & $5.11 \%$ \\
\hline $8 \%$ & $\$ 2,027.64$ & $\$ 121,658.37$ & $\$ 146,064.34$ & $\$ 1,275.62$ & $\$ 126,622.09$ & $4.83 \%$ & 37.75 & $\$ 115,144.43$ & 22.25 & $\$ 133,173.28$ & $5.90 \%$ \\
\hline $9 \%$ & $\$ 2,075.84$ & $\$ 124,550.13$ & $\$ 153,049.81$ & $\$ 1,275.62$ & $\$ 130,487.56$ & $5.47 \%$ & 36.87 & $\$ 116,718.69$ & 23.13 & $\$ 138,303.17$ & $6.70 \%$ \\
\hline $10 \%$ & $\$ 2,124.70$ & $\$ 127,482.27$ & $\$ 160,345.83$ & $\$ 1,275.62$ & $\$ 134,486.14$ & $6.10 \%$ & 36.02 & $\$ 118,223.03$ & 23.98 & $\$ 143,674.59$ & $7.52 \%$ \\
\hline $11 \%$ & $\$ 2,174.24$ & $\$ 130,454.54$ & $\$ 167,964.83$ & $\$ 1,275.62$ & $\$ 138,622.26$ & $6.75 \%$ & 35.2 & $\$ 119,658.39$ & 24.8 & $\$ 149,295.47$ & $8.35 \%$ \\
\hline $12 \%$ & $\$ 2,224.44$ & $\$ 133,466.69$ & $\$ 175,919.70$ & $\$ 1,275.62$ & $\$ 142,900.47$ & $7.40 \%$ & 34.41 & $\$ 121,025.86$ & 25.59 & $\$ 155,174.08$ & $9.19 \%$ \\
\hline $13 \%$ & $\$ 2,275.31$ & $\$ 136,518.44$ & $\$ 184,223.75$ & $\$ 1,275.62$ & $\$ 147,325.50$ & $8.06 \%$ & 33.64 & $\$ 122,326.68$ & 26.36 & $\$ 161,319.06$ & $10.04 \%$ \\
\hline $14 \%$ & $\$ 2,326.83$ & $\$ 139,609.51$ & $\$ 192,890.75$ & $\$ 1,275.62$ & $\$ 151,902.17$ & $8.72 \%$ & 32.89 & $\$ 123,562.25$ & 27.11 & $\$ 167,739.41$ & $10.90 \%$ \\
\hline $15 \%$ & $\$ 2,378.99$ & $\$ 142,739.58$ & $\$ 201,934.93$ & $\$ 1,275.62$ & $\$ 156,635.50$ & $9.39 \%$ & 32.17 & $\$ 124,734.06$ & 27.83 & $\$ 174,444.49$ & $11.77 \%$ \\
\hline $16 \%$ & $\$ 2,431.81$ & $\$ 145,908.34$ & $\$ 211,371.03$ & $\$ 1,275.62$ & $\$ 161,530.60$ & $10.07 \%$ & 31.47 & $\$ 125,843.69$ & 28.53 & $\$ 181,444.05$ & $12.65 \%$ \\
\hline $17 \%$ & $\$ 2,485.26$ & $\$ 149,115.45$ & $\$ 221,214.26$ & $\$ 1,275.62$ & $\$ 166,592.79$ & $10.75 \%$ & 30.8 & $\$ 126,892.80$ & 29.2 & $\$ 188,748.17$ & $13.55 \%$ \\
\hline $18 \%$ & $\$ 2,539.34$ & $\$ 152,360.56$ & $\$ 231,480.33$ & $\$ 1,275.62$ & $\$ 171,827.51$ & $11.43 \%$ & 30.14 & $\$ 127,883.12$ & 29.86 & $\$ 196,367.34$ & $14.45 \%$ \\
\hline $19 \%$ & $\$ 2,594.06$ & $\$ 155,643.31$ & $\$ 242,185.51$ & $\$ 1,275.62$ & $\$ 177,240.38$ & $12.13 \%$ & 29.5 & $\$ 128,816.42$ & 30.5 & $\$ 204,312.42$ & $15.36 \%$ \\
\hline $20 \%$ & $\$ 2,649.39$ & $\$ 158,963.30$ & $\$ 253,346.56$ & $\$ 1,275.62$ & $\$ 182,837.17$ & $12.83 \%$ & 28.89 & $\$ 129,694.49$ & 31.11 & $\$ 212,594.66$ & $16.28 \%$ \\
\hline $21 \%$ & $\$ 2,705.34$ & $\$ 162,320.16$ & $\$ 264,980.83$ & $\$ 1,275.62$ & $\$ 188,623.83$ & $13.53 \%$ & 28.29 & $\$ 130,519.16$ & 31.71 & $\$ 221,225.68$ & $17.21 \%$ \\
\hline $22 \%$ & $\$ 2,761.89$ & $\$ 165,713.47$ & $\$ 277,106.22$ & $\$ 1,275.62$ & $\$ 194,606.48$ & $14.24 \%$ & 27.71 & $\$ 131,292.26$ & 32.29 & $\$ 230,217.54$ & $18.15 \%$ \\
\hline $23 \%$ & $\$ 2,819.05$ & $\$ 169,142.83$ & $\$ 289,741.20$ & $\$ 1,275.62$ & $\$ 200,791.43$ & $14.96 \%$ & 27.15 & $\$ 132,015.64$ & 32.85 & $\$ 239,582.67$ & $19.09 \%$ \\
\hline $24 \%$ & $\$ 2,876.80$ & $\$ 172,607.79$ & $\$ 302,904.85$ & $\$ 1,275.62$ & $\$ 207,185.16$ & $15.68 \%$ & 26.6 & $\$ 132,691.11$ & 33.4 & $\$ 249,333.94$ & $20.05 \%$ \\
\hline $25 \%$ & $\$ 2,935.13$ & $\$ 176,107.94$ & $\$ 316,616.86$ & $\$ 1,275.62$ & $\$ 213,794.34$ & $16.41 \%$ & 26.08 & $\$ 133,320.50$ & 33.92 & $\$ 259,484.63$ & $21.01 \%$ \\
\hline $26 \%$ & $\$ 2,994.05$ & $\$ 179,642.82$ & $\$ 330,897.56$ & $\$ 1,275.62$ & $\$ 220,625.84$ & $17.15 \%$ & 25.56 & $\$ 133,905.60$ & 34.44 & $\$ 270,048.45$ & $21.98 \%$ \\
\hline $27 \%$ & $\$ 3,053.53$ & $\$ 183,211.96$ & $\$ 345,767.91$ & $\$ 1,275.62$ & $\$ 227,686.72$ & $17.89 \%$ & 25.07 & $\$ 134,448.18$ & 34.93 & $\$ 281,039.57$ & $22.96 \%$ \\
\hline $28 \%$ & $\$ 3,113.58$ & $\$ 186,814.92$ & $\$ 361,249.53$ & $\$ 1,275.62$ & $\$ 234,984.25$ & $18.63 \%$ & 24.58 & $\$ 134,949.97$ & 35.42 & $\$ 292,472.59$ & $23.94 \%$ \\
\hline $29 \%$ & $\$ 3,174.19$ & $\$ 190,451.22$ & $\$ 377,364.74$ & $\$ 1,275.62$ & $\$ 242,525.89$ & $19.39 \%$ & 24.11 & $\$ 135,412.70$ & 35.89 & $\$ 304,362.58$ & $24.93 \%$ \\
\hline $30 \%$ & $\$ 3,235.34$ & $\$ 194,120.38$ & $\$ 394,136.54$ & $\$ 1,275.62$ & $\$ 250,319.33$ & $20.14 \%$ & 23.66 & $\$ 135,838.00$ & 36.34 & $\$ 316,725.07$ & $25.93 \%$ \\
\hline
\end{tabular}


Figure 1: Compounding Annual Growth Rate (CAGR) comparison between

conventional, Standard and Accelerated MP at different interest rates in the market $(1 \%-30 \%)$ in a 30 years term loan.

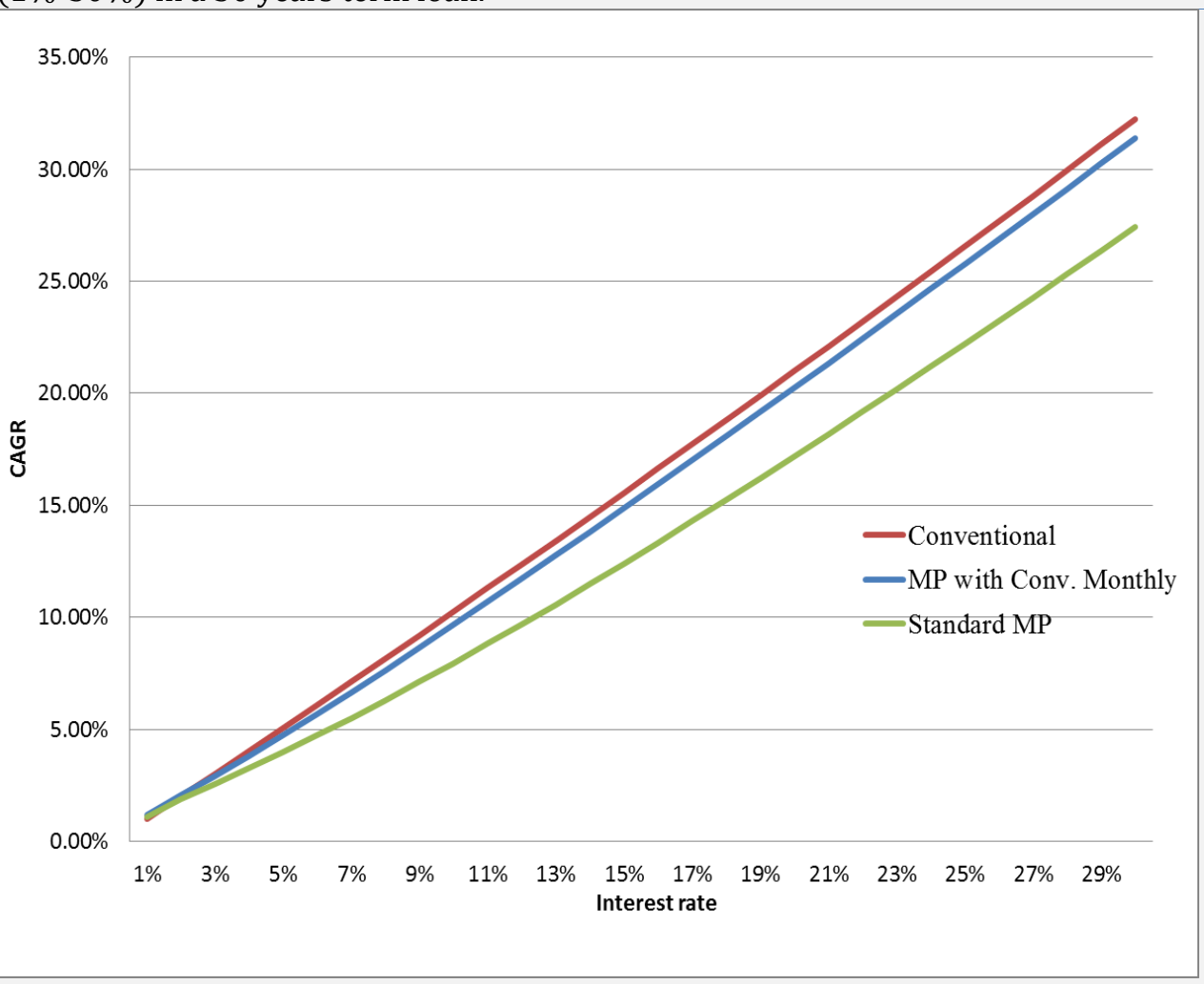

Figure 2: CAGR shortfalls in Standard MP and Accelerated MP in comparison with conventional at interest rates $1 \%$ to $30 \%$ during $5,10,15,20$ and 30 years terms.

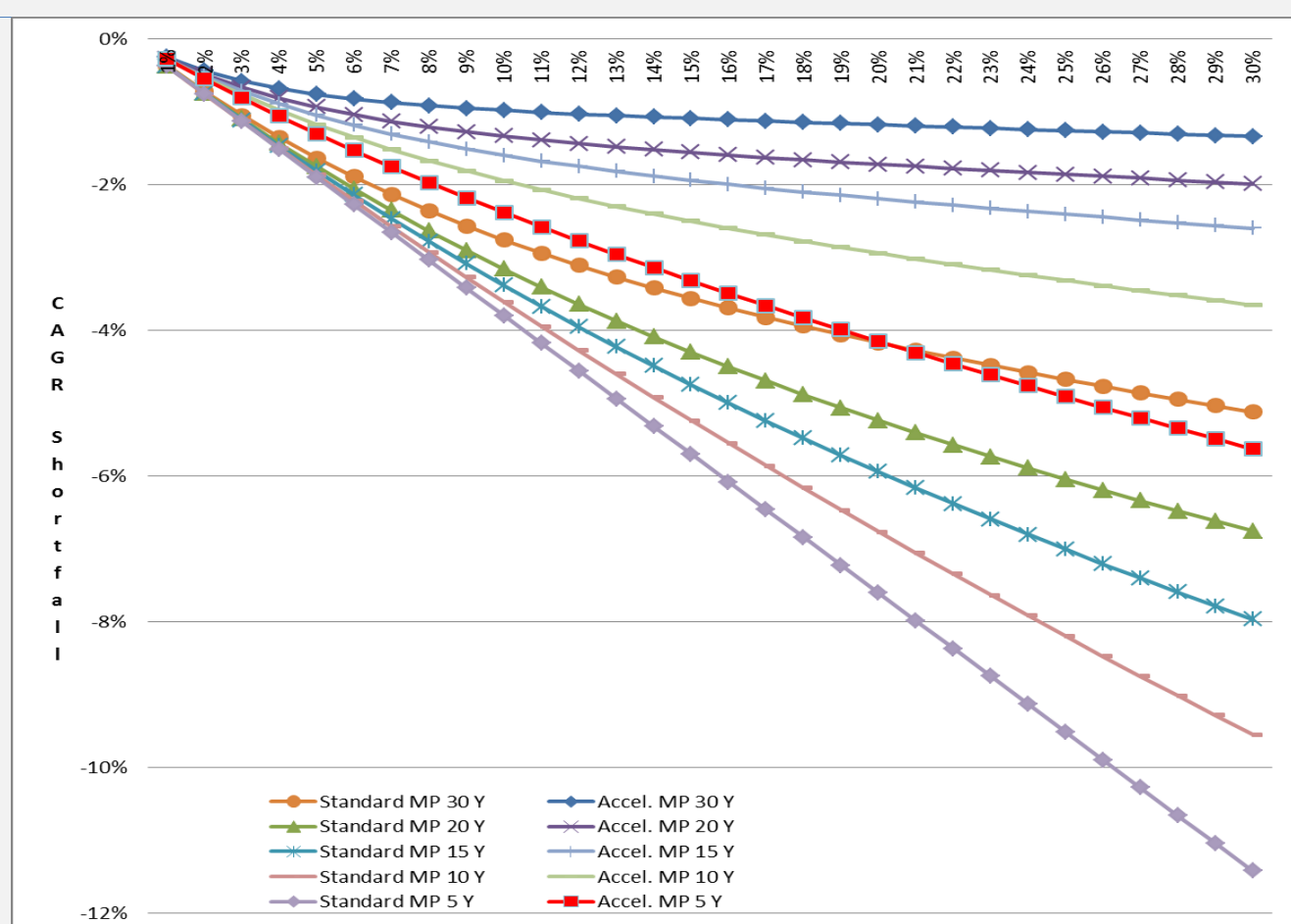




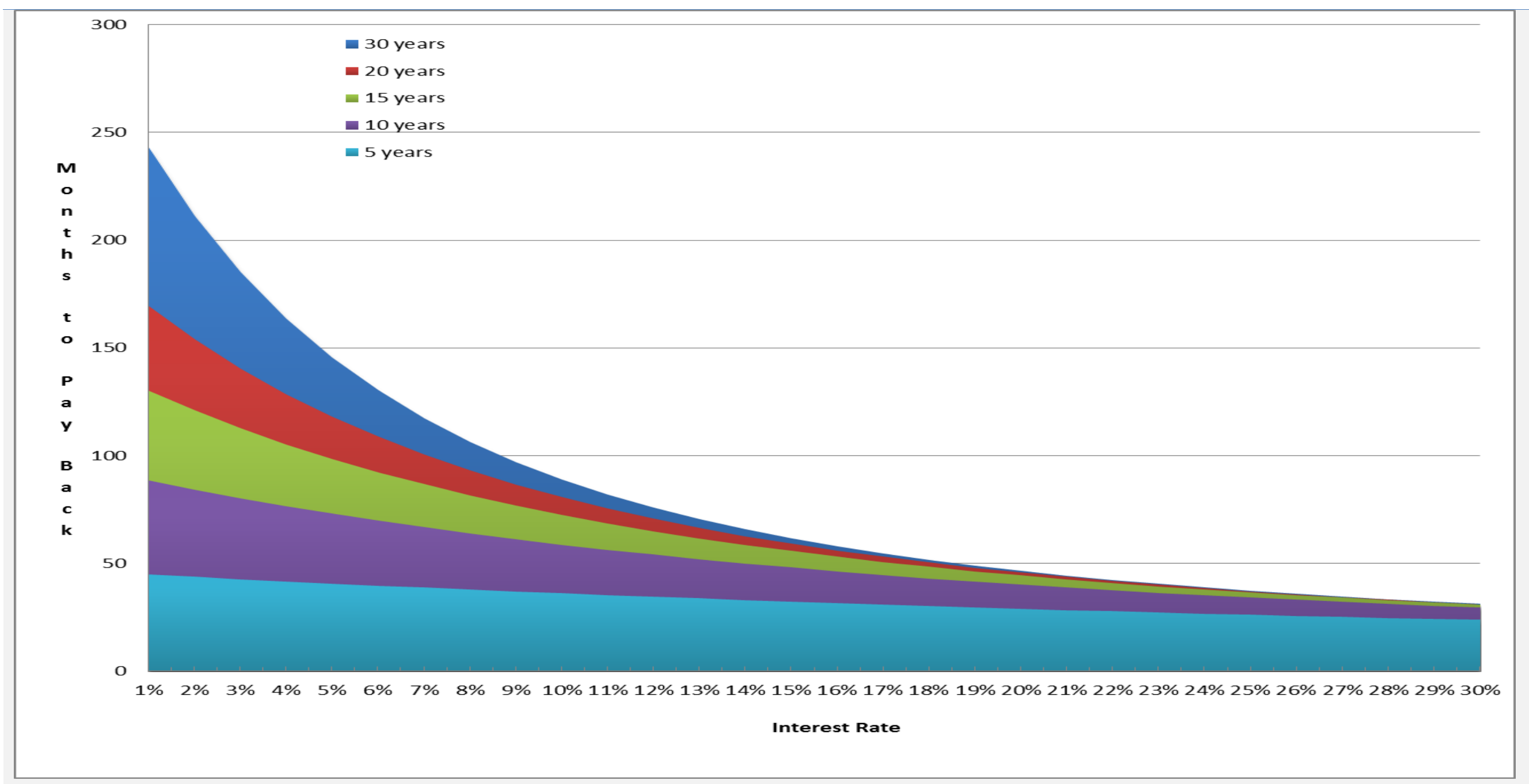

